\title{
The Analysis of Factors Which Influence Consumers' Willingness to Pay for the Pork Traceability System Based on RFID Technology
}

\author{
Yuanqiang LIAN \& Junfu LIU \\ Business school, Yangzhou University, China
}

\begin{abstract}
Traceability can be considered a key factor in agriculture-food sector. Based on the survey data of Yangzhou consumers, analyze the consumers' cognition of pork traceability system by descriptive statistics, and use regression analysis model to extract the main factors of influence customers' willingness to pay for traceable pork. The research obtains that three factors significantly influence on the customers' willingness to pay for traceable pork. They are that whether know the meaning of traceability, whether to go to supermarket to buy pork and whether queried traceable code. According to the conclusion of the research, this paper puts forward relevant policy suggestions to optimize the pork traceability system based on RFID technology.

KEYWORD: Pork Traceability System; Willingness to Pay; Regression Analysis Model; RFID
\end{abstract}

\section{INTRODUCTION}

Improving tracking and tracing without loosing data privacy is requested by both laws and market organizations. In many countries laws on traceability of agriculturefood have been made during last years. As the main meat of Chinese daily life, the quality and safety of Pork concerns the livelihood of the people. However, in recent years, pork safety accidents occur frequently has triggered intense attention. Due to the traceability system enables the only marking on product and tracking the whole process of production and consumption, is considered to be an effective method to solve the problem of food safety (Shi-ping Zhu etc., 2013). Therefore, there is an urgent need to establish pork traceability system to ensure the quality and safety of the pork.

The foundation and the core link of establishing traceability system is individual identification. Compared with other techniques, RFID has the advantages of easily read, strong penetrability, reusable, large data storage and high security, and so on. RFID is widely adopted as a contactless identification technology. Today, the size of the RFID tag memory allows recording directly on many agriculture commodities all useful information for the competent authorities to trace it. Therefore, applying RFID technology to pork supply chain, can well to track pig breeding, slaughtering, transportation, storage and sales, thus ensure the quality and safety of pork. (Yin-run-Lv, etc., 2013;
Juan Zhao etc., 2011) But compared with the traditional barcode, RFID tags cost higher, and in the process of the supply chain of traceability pork, information collection, and other items also increased the cost, will push up the market price of the pork, thus affect customers' willingness to pay for traceable pork. Meanwhile, the authenticity and validity of the information is also likely to affect the consumers' consumption desire and willingness to buy for traceable pork. Data acquisition and transmission of new methods based on RFID help consumers to obtain information effectively and to some extend. It can be able to ensure that the information is relatively real and effective.

For the issue of consumers' willingness to pay for meat traceability system, foreign scholars have done a lot research. Dickinson, Hobbs and Bailey (2003) through auction experiment measured the U.S. and Canadian consumers' willingness to pay for the beef that affixed label of the traceable information, the results show that: most consumers in the two countries have the willingness to pay for the beef affixed label that can be traced. Angelo and Gil (2005) found that, the beef with traceable label, Spanish consumers' willingness to pay influenced by the perception of food scares and the negative impact on the environment for agricultural produce.

The literature of Chinese scholars on meat traceability system is relatively abundant. Research focuses on the design and implementation of pork traceability system that based on RFID technology, two-dimensional code technology and the internet of 
things technology (Wei Song, 2014), the research progress of pork and agricultural product traceability system based on RFID technology and so on. (Zhu Shiping, etc., 2013, Chen Qingang etc., 2013).lin-hai Wu etc. (2012) analyzed consumers' preferences for traceability pork with different quality and safety information based on orderly logistic regression model, the results indicate that the variables that the degree of consumers concern about food quality and safety, cognition of traceability food, etc. significantly affect their preferences on traceable pork with different quality and safety information.

As final buyers of pork products, consumers are not only the receivers of safety information of pork, but also the respondents of the construction of pork traceability system. Their acceptance and willingness to pay for the pork traceability system and factors which affect their willingness will play a crucial role for perfecting the pork traceability system.

\section{SAMPLE SOURCE AND SAMPLE DESCRIPTION}

This research, combined the characteristics of pork consumption with literature review, summarized the factors that affect consumers' willingness to pay for traceability pork, and next design the questionnaire. The survey sites are some supermarkets and farmers' markets. The questionnaires were distributed 430 and returned 390 . The $90.6 \%$ of questionnaires were effective. The table 1 below gives basic characteristics of the sample:

Table 1 Basic characteristics of the sample

\begin{tabular}{|c|c|c|c|c|}
\hline \multicolumn{2}{|c|}{ Characteristic } & \multirow{2}{*}{\begin{tabular}{|l|}
$\begin{array}{l}\text { Sample } \\
\text { size }\end{array}$ \\
150 \\
240 \\
\end{tabular}} & \multirow{2}{*}{$\begin{array}{l}\text { Percentage } \\
(\%) \\
38.5 \\
61.5\end{array}$} & \multirow{2}{*}{\begin{tabular}{|l} 
Cumulative \\
Percentage \\
$(\%)$
\end{tabular}} \\
\hline Gender & $\begin{array}{l}\text { male } \\
\text { female }\end{array}$ & & & \\
\hline Age & $\begin{array}{l}25 \text { and below } \\
26-35 \\
36-45 \\
46-55 \\
56 \text { and older }\end{array}$ & $\begin{array}{l}12 \\
182 \\
126 \\
51 \\
19\end{array}$ & $\begin{array}{l}3.1 \\
46.7 \\
32.3 \\
13.1 \\
4.9\end{array}$ & $\begin{array}{l}3.1 \\
49.8 \\
82.1 \\
95.2 \\
100\end{array}$ \\
\hline 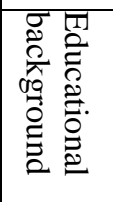 & $\begin{array}{l}\text { Primary } \\
\text { Junior high } \\
\text { senior high } \\
\text { Bachelor degree } \\
\text { Masters \& above }\end{array}$ & \begin{tabular}{|l|}
8 \\
57 \\
114 \\
186 \\
25
\end{tabular} & \begin{tabular}{|l|}
2.1 \\
14.6 \\
29.2 \\
47.7 \\
6.4
\end{tabular} & $\begin{array}{l}2.1 \\
16.7 \\
45.9 \\
93.6 \\
100\end{array}$ \\
\hline $\begin{array}{l}\text { Marital } \\
\text { status }\end{array}$ & $\begin{array}{l}\text { married } \\
\text { Spinsterhood }\end{array}$ & $\begin{array}{l}358 \\
32 \\
\end{array}$ & $\begin{array}{l}91.8 \\
8.2 \\
\end{array}$ & \begin{tabular}{|l|}
91.8 \\
100 \\
\end{tabular} \\
\hline $\begin{array}{l}\overline{8} \\
\delta \\
0 \\
0 \\
\frac{0}{2} \\
\frac{0}{\infty}\end{array}$ & $\begin{array}{l}1000 \text { and below } \\
1001-2000 \\
2001-3000 \\
3001-4000 \\
4001-5000 \\
5001-6000 \\
\text { More than } 6000\end{array}$ & $\begin{array}{l}21 \\
75 \\
116 \\
84 \\
42 \\
19 \\
33\end{array}$ & \begin{tabular}{|l|}
5.4 \\
19.2 \\
29.7 \\
21.5 \\
10.8 \\
4.9 \\
8.5
\end{tabular} & \begin{tabular}{|l|}
5.4 \\
24.6 \\
54.4 \\
75.9 \\
86.7 \\
91.5 \\
100
\end{tabular} \\
\hline
\end{tabular}

Consumers concerned about the quality and safety for pork or not are the basis of expanding this research. Statistical results in Table 2 show that the high degree of consumers concerned about the quality and safety for pork, there is a good basis for the implementation of pork traceability system.

Table 2 The degree of consumers concerned about the quality and safety for pork

\begin{tabular}{|c|c|c|c|c|c|}
\hline percentage & $\begin{array}{c}\text { Totally } \\
\text { not } \\
\text { concerned }\end{array}$ & $\begin{array}{c}\text { Less } \\
\text { concerned }\end{array}$ & $\begin{array}{c}\text { Does } \\
\text { not } \\
\text { matter }\end{array}$ & $\begin{array}{c}\text { more } \\
\text { attention }\end{array}$ & $\begin{array}{c}\text { Very } \\
\text { concerned }\end{array}$ \\
\hline$(\%)$ & 1.3 & 16.4 & 2.3 & 55.4 & 24.6 \\
\hline
\end{tabular}

Consumers' understanding of the pork traceability system is also very important. Survey results (Table 3 ) showed that a large proportion of respondents, did not notice pork traceability code, indicating that consumers lack basic knowledge on the whole pork traceability system.

Table 3 Consumers' awareness of pork traceability system

\begin{tabular}{|c|c|c|}
\hline \multirow{2}{*}{ Consumer awareness } & Noticed & $\begin{array}{c}\text { Percentage } \\
(\%)\end{array}$ \\
\cline { 2 - 3 } & Not noticed & 21.3 \\
\hline $\begin{array}{c}\text { Whether noticed pork } \\
\text { traceability code }\end{array}$ & Do not know & 78.7 \\
\cline { 2 - 3 } & Know a little & 43.3 \\
\cline { 2 - 3 } $\begin{array}{c}\text { Whether know } \\
\text { the meaning of pork } \\
\text { traceability }\end{array}$ & General & 39.2 \\
\cline { 2 - 3 } & Know more & 10.0 \\
\hline \multirow{2}{*}{$\begin{array}{c}\text { Whether queried } \\
\text { traceable code }\end{array}$} & Know a lot & 1.3 \\
\cline { 2 - 3 } & queried, but did not found & 4.6 \\
\cline { 2 - 3 } & queried and found & 1.5 \\
\hline
\end{tabular}

We enquired consumers that what kind of pork want to buy, the results (Table 4) showed that most respondents want to buy quality assurance and traceable pork, we can see that whether the pork can be tracked is not the decisive factor for consumers to buy pork, possibly because that in the mind of consumers, pork traceability is not guaranteed safety and quality for pork.

Table 4 what kind of pork you want to buy

\begin{tabular}{|l|l|l|l|}
\hline & $\begin{array}{l}\text { Pork can } \\
\text { be traced }\end{array}$ & $\begin{array}{l}\text { Pork that quality } \\
\text { assurance }\end{array}$ & $\begin{array}{l}\text { Quality assurance } \\
\text { and can be traced }\end{array}$ \\
\hline Percentage(\%) & 3.6 & 23.6 & 72.8 \\
\hline
\end{tabular}

\section{REGRESSION ANALYSIS OF CONSUMERS' WILLINGNESS TO PAY}

In this research, the independent variables are whether consumers concerned about the quality and safety of pork, whether to go to supermarket to buy pork, whether noticed pork traceability code and so 
on. We set the independent variables as $\mathrm{X} 1-$ $\mathrm{X} 10$.The dependent variable is the higher price that consumers' willingness to pay for the traceability pork than the ordinary pork. The regression model is that:

$$
\begin{aligned}
Y= & a+b_{1} X_{1}+b_{2} X_{2}+b_{3} X_{3}+b_{4} X_{4}+b_{5} X_{5}+b_{6} X_{6} \\
& +b_{7} X_{7}+b_{8} X_{8}+b_{9} X_{9}+b_{10} X_{10}
\end{aligned}
$$

The definition of variables and value meaning are as Table 5:

\begin{tabular}{|c|c|c|c|c|}
\hline Variables I & s Definition & Value & value meanings & anticipate \\
\hline $\mathrm{X} 1$ & $\begin{array}{l}\text { Concerned } \\
\text { about quality } \\
\text { and safety of } \\
\text { pork }\end{array}$ & $1-5$ & $\begin{array}{l}\text { Totally not } \\
\text { concerned=1, } \\
\text { less concerned=2, } \\
\text { does not matter=3, } \\
\text { more concerned }=4, \\
\text { very concerned=5 }\end{array}$ & + \\
\hline $\mathrm{X} 2$ & $\begin{array}{l}\text { to supermarket } \\
\text { to buy pork }\end{array}$ & $1-5$ & $\begin{array}{l}\text { never }=1, \\
\text { seldom }=2, \\
\text { occasionally=3, } \\
\text { frequently }=4, \\
\text { everyday }=5\end{array}$ & + \\
\hline X3 & $\begin{array}{l}\text { Noticed pork } \\
\text { traceability } \\
\text { code }\end{array}$ & 0,1 & $\begin{array}{l}\text { Not noticed }=0 \text {, } \\
\text { Noticed }=1\end{array}$ & + \\
\hline $\mathrm{X} 4$ & $\begin{array}{l}\text { Know the } \\
\text { meaning of } \\
\text { pork } \\
\text { traceability }\end{array}$ & $1-5$ & $\begin{array}{l}\text { Do not know=1, } \\
\text { Know a little=2, } \\
\text { General=3, } \\
\text { Know more=4, } \\
\text { Know a little=5 }\end{array}$ & + \\
\hline X5 & $\begin{array}{l}\text { queried } \\
\text { traceable code }\end{array}$ & $1-3$ & $\begin{array}{l}\text { No queried=1, } \\
\text { queried, but did not } \\
\text { found }=2 \text {, } \\
\text { queried and found }=3\end{array}$ & + \\
\hline X6 & Gender & 0,1 & female $=0$, male $=1$ & - \\
\hline X7 & Age & $1-5$ & $\begin{array}{l}25 \text { and below }=1, \\
26-35=2, \\
36-45=3, \\
46-55=4, \\
56 \text { and older }=5\end{array}$ & + \\
\hline $\mathrm{X} 8$ & Marital status & 0,1 & $\begin{array}{l}\text { married }=0, \\
\text { spinsterhood }=1\end{array}$ & + \\
\hline X9 & $\begin{array}{l}\text { Educational } \\
\text { background }\end{array}$ & $1-5$ & $\begin{array}{l}\text { Primary }=1, \\
\text { Junior high }=2, \\
\text { senior high }=3, \\
\text { Bachelor degree }=4, \\
\text { Master's and above }=5\end{array}$ & + \\
\hline $\mathrm{X}_{10}$ & Income levels & $1-5$ & $\begin{array}{l}1000 \text { and below }=1, \\
1001-2000=2, \\
2001-3000=3, \\
3001-4000=4, \\
4001-5000=5, \\
5001-6000=6, \\
\text { more than } 6000=7\end{array}$ & + \\
\hline
\end{tabular}

Table 5 Variables definition and value meanings

Y The higher price that consumers willingness to pay for the traceability pork than the ordinary pork

This article uses SPSS16.0 software, using the term culling method to estimate the regression model, the regression results are as Table 6:
Table 6 Regression results

\begin{tabular}{|l|l|l|l|l|l|}
\hline Variables & \multicolumn{2}{|l|}{$\begin{array}{l}\text { Unstandardized } \\
\text { Coefficients }\end{array}$} & $\begin{array}{l}\text { Standard } \\
\text { coefficient }\end{array}$ & $\mathrm{t}$ & Sig. \\
\hline & $\mathrm{B}$ & $\begin{array}{l}\text { Standard } \\
\text { error }\end{array}$ & & & \\
\hline Constant & 1.001 & .322 & & 3.108 & .002 \\
\hline $\begin{array}{l}\text { whether to go to } \\
\text { supermarket to } \\
\text { buy pork }\end{array}$ & -.222 & .079 & -.142 & -2.801 & .005 \\
\hline $\begin{array}{l}\text { whether know the } \\
\text { meaning of } \\
\text { traceability }\end{array}$ & .166 & .086 & .103 & 1.930 & .045 \\
\hline $\begin{array}{l}\text { Whether queried } \\
\text { the information } \\
\text { about pork } \\
\text { traceability }\end{array}$ & .630 & .250 & .134 & 2.518 & .012 \\
\hline
\end{tabular}

According to the significant judgment, get the regression equation:

$$
Y=1.001-0.222 X_{2}+0.166 X_{4}+0.630 X_{5}
$$

As we can see from the results of the regression analysis, whether consumers know the meaning of traceability, whether to go to supermarket to buy pork and whether queried traceable code significantly influence on the customers' willingness to pay for traceable pork. The relationship between whether to go to the supermarket to buy pork and consumers' willingness to pay for traceable pork presented negatively correlated. The reason may be that consumers may lose the trust to enterprises and supermarkets, thus affecting their confidence in the traceability pork. Bin Cui, Jing-jing Yi (2012) through their research showed that consumers' trust on the food safety significantly affected by their confidence in relevant food supplier and the relevant regulatory bodies. Secondly, the relationship between whether know the meaning of pork traceability and the consumer's willingness presented positively correlated, indicating that consumers the more understanding of pork traceability, the more learn about the properties and functions of pork traceability, the more likely to pay a premium to traceability pork. Whether queried the information about pork traceability, also through the test of significance, if consumers queried the traceable information on Internet, then they have stronger willingness to pay for it, probably because that it can increase their level of trust to pork traceability. And produce good impression to pork traceability.

\section{SUMMARY AND RECOMMENDATIONS}

This paper takes pork consumers of Yangzhou as investigation object, uses the regression analysis model to analyze the consumer's willingness to pay for pork traceability system and its influenced factors. Now its conclusions and policy implications summed up as follows: 
Firstly, the consumers' awareness of pork quality and safety is higher and higher. Pork traceability system is necessary to be established and perfected. Consumers not only consider the price factor when they buying pork, but also consider more factors such as pork quality and safety. They wish to buy the pork of quality assured and can trace its origin. Establishment of pork traceability system can realized a directional recall to that in the event of pork security incidents, to avoid further incidents. While it also can strengthen the supervision of the government as well as raising awareness of integrity for related businesses, there by enhancing consumers' sense of security of pork consumption.

Secondly, consumers' cognition of pork's very low. These results of the research are consistent with the results of Zhi-gang Wang etc. (2013). After strengthening consumer's perception of pork traceability, most consumers believe that it is necessary to implement pork traceability system, and the majority of consumers willing to buy the traceable pork, that the traceability system can increase their confidence. This again, enhancing the understanding of the traceability system has played a significant role in promoting consumers to buy the traceability pork. Therefore, the government should strengthen the propaganda, widely publicized the role of the traceability system in pork safety, and promote consumers to self-learning, so that to consolidate and enhance the status of traceability system for consumers.

Thirdly, The extent of queried the traceability code for consumers is very low. Most consumers did not query the traceability code, the reason may be that for consumers, the perception of the traceability system is low and the consciousness of query is not strong. Another reason may be that existing way of query is more tedious, it needs to $\log$ in to website, and enter the traceability code. So, the relevant departments should optimize operating platform of pork traceability system, investment in mobile applications for querying the traceability information or make use of two-dimensional code technology and RFID to optimize the service, increase the rate of consumers query the traceability information, and improving consumer willingness to pay for pork traceability system. In short, the traceability of pork products supply chain based on RFID can be significantly enhanced.

\section{ACKNOWLEDGEMENT}

This paper is a part of research results about project supported by the National Natural Science Foundation of China (Grant No. 71103155).

\section{REFERENCES}

[1] Yin-run Lu, Li-min Zheng. Research progress on the RFID technology which is applied to animal product traceability system. Journal of meat research, 2013(5): 2630

[2] Juan Zhao. Pork supply chain traceability system research based on RFID. Journal of electronic technology, 2011 (8): $45-46$

[3] Dickinson David L, Hobbs Jill E, Dee. Von Bailey. A Comparison of the US and Canadian Consumers' Willingness to Pay for Red Meat-Traceability. J American Agricultural Economics Association Annual Meeting, 2003 (7): 4-9.

[4] Angulo A M, Gil J M, Tamburo 1. The Food safety and consumers' willingness to pay for labeled beef in. Journal of Food Products Marketing, 2005, 11 (3): 89-105.

[5] Wei Song. The design and implementation of pork safety traceability system based on RFID.Master degree theses of Xiamen University. 2014

[6] Shi-ping Zhu, Wen-hua Dong, Ying Liu etc. RFID research progress on the pork safety traceability system. Journal of China animal husbandry and veterinary, 2014 (7): 202-107

[7] Qin-gang Chen, Ben-xue Ma, feng-xia Li etc. Research progress of livestock product quality and safety traceability system based on RFID. Journal of agricultural mechanization research, 2013 (8): 224-227

[8] Lin-hai $\mathrm{Wu}$, fan $\mathrm{Bu}$, dian Zhu. The consumers' consumption preference analysis to traceability pork of containing different information of quality and safety. China's rural economy, 2012 (10): 13-23

[9] Bin Cui, Jing Jing Yi.Empirical research of consumers' food safety trust formation mechanism-- based on the 862 survey data of Jiangsu province. The economic frame. 2012 (2): 115-119 